Journal of Nutraceuticals and Herbal Medicine

Journal Homepage: http://journals.ums.ac.id/index.php/jnhm

\title{
Formulation of Mouthwash Preparations Ethanol Extract of Coffee Beans Roasted Robusta (Coffea canephora) and Effectiveness Test on Bacteria Streptococcus mutans
}

\author{
Syaifur Rahman', Reni Ariastuti², ${ }^{2}$ Ahwan $^{3}$
}

1. Faculty of Science, Technology, and Health, University of Sahid Surakarta Surakarta, Central Java, Indonesia ovdmamank@gmail.com

2. Faculty of Science, Technology, and Health, University of Sahid Surakarta Surakarta, Central Java, Indonesia reniariafarmasi@usahidsolo.ac.id

3. Faculty of Science, Technology, and Health, University of Sahid Surakarta Surakarta, Central Java, Indonesia ahone.far02@gmail.com

\begin{abstract}
Dental caries can be caused by Streptococcus mutans bacteria. Robusta coffee bean extract has an inhibitory effect on the growth of Streptococcus mutans bacteria. Compounds that have antibacterial activity are chlorogenic acid (CGA), caffeine, caffeic acid and trigonelline. Robusta coffee bean extract has the potential to be formulated into mouthwash. This study aims to make a mouthwash formula with the active ingredient of roasted Robusta coffee extract and then evaluate the preparation and test its effectiveness against $S$. mutans bacteria. Mouthwash preparations were made in 3 formulas with different glycerin concentrations, namely $5 \%, 10 \%$, and $15 \%$. The stability test of the preparation used the treatment before and after the forced condition. Bacterial inhibition test using agar diffusion method with the positive control, namely commercial mouthwash Chlorhexidine and negative control mouthwash formula without extract content. Data analysis used the Kruskal-Wallis test to determine the differences in each treatment, and the Mann-Whitney test to see which treatment groups were significantly different. The results of the evaluation of the stability of the preparation showed that the three formulations of the mouthwash of roasted Robusta coffee bean extract had organoleptic stability, $\mathrm{pH}$, and viscosity. The results of the inhibitory effectiveness test showed that the mouthwash formulation of formula 1 produced an inhibition zone of 1.6 $\mathrm{mm}$, formula 2 of $2.1 \mathrm{~mm}$, formula 3 of $2.4 \mathrm{~mm}$, positive control of $6.8 \mathrm{~mm}$, and negative control did not produce obstacles zone. It can be concluded that the three mouthwash formulas have antibacterial activity in the weak category $(<5 \mathrm{~mm})$. The concentration of glycerin in the formula had no significant effect on the stability of the preparation and the antibacterial effectiveness of $S$. mutans. The results of the inhibitory effectiveness test showed that the mouthwash formulation of formula 1 produced an inhibition zone of 1.6 $\mathrm{mm}$, formula 2 of $2.1 \mathrm{~mm}$, formula 3 of $2.4 \mathrm{~mm}$, positive control of $6.8 \mathrm{~mm}$, and negative
\end{abstract}


control did not produce obstacles zone. It can be concluded that the three mouthwash formulas have antibacterial activity in the weak category $(<5 \mathrm{~mm})$. The concentration of glycerin in the formula had no significant effect on the stability of the preparation and the antibacterial effectiveness of $S$. mutans. The results of the inhibitory effectiveness test showed that the mouthwash formulation of formula 1 produced an inhibition zone of 1.6 $\mathrm{mm}$, formula 2 of $2.1 \mathrm{~mm}$, formula 3 of $2.4 \mathrm{~mm}$, positive control of $6.8 \mathrm{~mm}$, and negative control did not produce obstacles zone. It can be concluded that the three mouthwash formulas have antibacterial activity in the weak category $(<5 \mathrm{~mm})$. The concentration of glycerin in the formula had no significant effect on the stability of the preparation and the antibacterial effectiveness of $S$. mutans.

Keywords: Robusta coffee (Coffea canephora); the bacteria S. mutans; mouthwash formulations; antibacterial.

\section{INTRODUCTION}

Coffee is one of the fruits that is processed into drinks and is often consumed by the people of Indonesia. One type of coffee that is in great demand is Robusta coffee. Robusta coffee (Coffea canephora) is widely grown in Africa, India, and Indonesia. Robusta coffee commodity in Indonesia is very high so that it can dominate the national market, but only controls $30 \%$ of the world market compared to Arabica coffee which is $70 \%$ (Tanauma et al., 2016). Robusta coffee production centers in Central Java are in Temanggung Regency (30.27\%), Semarang and Salatiga (10.86\%), Kendal (8.69), Jepara (7.67\%), and Wonosobo (6.06\%) (Oelviani, 2017).

Chemical content in robusta coffee beans is alkaloid compounds, tannins, saponins, and polyphenols (Chairgulprasert, 2017). Caffeine is one of the most important alkaloid compounds in coffee beans which can inhibit bacterial growth. The caffeine content in robusta coffee beans is around 1.6\%-2.4\% (Tanauma et al., 2016). In addition to caffeine, another important compound is polyphenol compounds. The most abundant polyphenolic compounds in coffee are chlorogenic acid and caffeic acid. The amount of chlorogenic acid reaches $90 \%$ of the total phenol found in coffee (Yusmarini, 2011). The content of chlorogenic acid in coffee beans is about $8 \%$ or $4.5 \%$ in roasted coffee. During roasting, most of the chlorogenic acid becomes caffeic acid and quinic acid (Yusianto and Dwi, 2014).

The results of Yaqin and Nurmilawati (2015) research on the effect of robusta coffee extract (Coffea canephora) as an inhibitor of the growth of Staphylococcus aureus bacteria showed that robusta coffee extract could inhibit Staphylococcus aureus with a minimum concentration of $12.5 \%$ and the most effective inhibitory power was a concentration of $100 \%$. Another study conducted by Chamidah (2012), stated that robusta coffee bean extract has antibacterial power against the growth of Porphyromonas gingivalis at concentrations of $100 \%, 50 \%$, and $25 \%$. Compounds that have antibacterial activity are chlorogenic acid (CGA), caffeine, caffeic acid, and trigonelline (Siebert et al., 2018). Apart from being antibacterial, robusta coffee extract also has antioxidant and anti-inflammatory activity (Almeida et al., 2012).

Robusta coffee bean ethanol extract also has an inhibitory power against bacteria that cause dental plaque, namely Streptococcus mutans starting at a concentration of 
$1.56 \%$, (Maheswari et al., 2015). Streptococcus mutans is a cariogenic bacteria because it is able to stick to the tooth surface(Rahman et al., 2017) and is a bacterium that often causes dental caries (Dewi et al., 2015). Prevention efforts need to be made to control caries risk factors. One of the efforts to control the causes of dental caries is the use of antibacterial mouthwash. The use of commercial antibacterials turns out to have some side effects such as changes in normal flora and resistance of microorganisms in the oral cavity(Rahman et al., 2017). This prompted researchers to formulate mouthwash with active ingredients derived from herbal ingredients, namely ethanol extract of roasted robusta coffee beans. Many types of research on the activity of robusta coffee bean extract have been carried out, but there is still little research on the activity in the dosage form, especially as an antibacterial for the oral cavity. In addition, many factors influence the occurrence of differences in chemical components in robusta coffee bean extract, namely the heating or roasting of green coffee beans or also called "roasted coffee", genetic factors, cultivars, cultivation processing practices by farmers, climate, soil type, and the environment. around(Farah et al., 2012). Differences in these components will affect the level of activity. Therefore, the researcher intends to determine the activity of robusta coffee bean extract in the form of mouthwash preparations. The robusta coffee bean extract used comes from local farmers in the Wonosobo area, Central Java, where the coffee has been heated or roasted (roasted coffee).

\section{METHOD}

The tools used in this research are rotary evaporator (Bio Base), autoclave (Model YXQ.SG41.46.280AS), measuring pipette (pyrex), ose, micropipette (Dragon Onemed), Bunsen, analytical balance (ACIS), caliper, laminar flow (WINA Type 304), incubator (WINA Type 801), cup (Normax), Ostwald viscometer, and glassware.

The materials used in this study were ethanol extract of roasted robusta coffee beans, xylitol (Brataco), glycerin (Brataco), sodium benzoate, methylparaben, propylparaben, aqua dest, ethanol, disc, Streptococcus mutans bacteria obtained from the Pro Technology Laboratory, Nutrien Agar (Merch), Nutrien Broth (Merch), and Muller Hinton Agar (Merch).

This type of research is the experimental laboratory. The research design used was a post-test-only control group design. The sample used in this study is roasted robusta coffee beans (Coffea canephora) which are sold in Kepil District, Wonosobo Regency.

The samples obtained were macerated with $96 \%$ ethanol. The resulting extract was subjected to phytochemical screening. Then a mouthwash was formulated with ingredients, namely $6 \%$ roasted robusta coffee bean extract, xylitol, glycerin, sodium benzoate, methylparaben, propylparaben, and aqua dest. Made in 3 formulas with different concentrations of glycerin, namely 5\%,10\%, and 15\%. The mouthwash formula made was evaluated for preparations including organoleptic, $\mathrm{pH}$, and viscosity tests under conditions before and after conditions were imposed. After evaluating the preparation, the mouthwash formula was tested for effectiveness on S. mutans bacteria. The following is the procedure for testing the antibacterial effectiveness of roasted robusta coffee bean mouthwash preparations. 


\section{Preparation of Nutrient Agar (NA) Lean Media and Inoculation of S. mutans . Bacteria}

A total of $2.8 \mathrm{~g}$ of NA was put into an Erlenmeyer and added $100 \mathrm{~mL}$ of sterile distilled water. Heated on the stove until homogeneous. Covered with cotton and then sterilized for 15 minutes in an autoclave at $121^{\circ} \mathrm{C}$. Pour $5 \mathrm{~mL}$ into a sterile test tube. The media is placed with the desired slope and wait for it to harden. The bacteria obtained from the Pro Technology Laboratory were tightly etched on the media so that it tilted in a zigzag fashion from bottom to top. Then the cultures were incubated at room temperature (37으) for 24 hours (Mahmudah and Atun, 2017).

\section{Preparation of Liquid Media and Suspension of S. mutans}

Liquid medium was prepared from Nutrient broth (NB). Weighing $3.25 \mathrm{~g}$ of NB was put into an Erlenmeyer, added $250 \mathrm{~mL}$ of distilled water. The media is heated on an electric stove and stirred until it boils and is homogeneous. The homogeneous media was poured into $50 \mathrm{~mL}$ Erlenmeyer as much as $30 \mathrm{~mL} \mathrm{NB}$. Sterilized using autoclave for 15 minutes at a temperature of $121^{\circ} \mathrm{C}$. The media was allowed to stand for 24 hours.

Planting of bacteria in liquid media is done by taking one colony of bacteria on slanted agar media that has been grown previously using a sterile ose needle, then inserted into the liquid medium. Bacteria in liquid media were then incubated for 24 hours at $37^{\circ} \mathrm{C}$. The growth of $S$. mutans was indicated by the presence of turbidity in the media (Maheasy and Atun, 2017).

\section{Production of Muller Hinton Agar (MHA) Media}

Weigh $38 \mathrm{~g}$ of MHA media, then add $1000 \mathrm{~mL}$ of distilled water. The MHA medium was stirred and heated using a hot plate. The MHA media was sterilized by autoclave for 15 minutes at a temperature of $121^{\circ} \mathrm{C}$. Then the media was poured into sterile Petri dishes as much as $15 \mathrm{~mL}$ and the work was carried out in the LAF (Maheasy and Atun, 2017).

\section{Inhibitory Test Phase}

Streptococcus mutans inhibition test was assessed using the agar diffusion method. This research was conducted using 3 empty plates and 15 discs. The disc paper was soaked for 5 minutes in each formula and control.

a. Formula 1, mouthwash with $5 \%$ glycerin concentration

b. Formula 2, mouthwash with $10 \%$ glycerin concentration

c. Formula 3, mouthwash with $15 \%$ glycerin concentration

d. Control (+), mouthwash Minosep® (Chlorhexidine)

e. Control (-), mouthwash formula that does not contain roasted robusta coffee bean extract.

In each petri dish containing MHA medium $0.1 \mathrm{~mL}$ of Streptococcus mutans suspension was inoculated, then 5 paper Blancs were placed from 5 different treatments. Do 3 repetitions. Incubated for 24 hours at $37^{\circ} \mathrm{C}$. After 24 hours, the Petri dishes were removed from the incubator and then the clear zone or zone of inhibition seen on each disc was measured using a caliper. Measurements were carried out 3 times by different people who previously had equalized perceptions and taken the average (Maheasy and Atun, 2017). If the inhibition zone is oval, then measurements are made on the long 
diameter (eg an $\mathrm{mm}$ ) and the short diameter (eg $\mathrm{b} \mathrm{mm}$ ) then both are added and divided by two. So the diameter of the inhibition zone $(x)=(a+b) / 2$.

The research data were tested for normality with the Kolmogorov Smirnov test and homogeneity test with the Levene Test. If both tests show normal and homogeneous data ( $p>0.05$ ), then a parametric statistical test is carried out, namely One Way Anova. However, if the data is not normally distributed and/or not homogeneous, it is continued with a nonparametric statistical test, namely Kruskal Wallis.

\section{RESULTS AND DISCUSSION}

\section{Making Roasted Robusta Coffee Bean Ethanol Extract}

The extraction of roasted robusta coffee beans produces an extract with the characteristics of a thick blackish-brown liquid, and has a distinctive aroma of roasted coffee. The thick extract obtained after concentration was $9.68 \mathrm{~g}$ with a yield of $4.84 \%$. The yield obtained is slightly lower when compared to previous research conducted by Kiattisin et al (2016), the yield obtained from the maceration of roasted robusta coffee beans is $5.43 \%$. The difference in the yield value can be caused by several factors including the size of the simplicia, the extraction time, and the concentration of the solvent used (Juliantari et al., 2018). The results of phytochemical screening showed that the ethanol extract of roasted robusta coffee beans was positive for alkaloids, flavonoids, tannins, and saponins. This is following previous research conducted by Utami et al, (2018).

\section{Roasted Robusta Coffee Bean Extract Mouthwash Formulation}

The preparation of ethanol extract mouthwash preparations of roasted robusta coffee beans is based on the formulation in the research of Gowtham et al, (2020). Making mouthwash requires ingredients, namely thick roasted robusta coffee bean extract, xylitol, glycerin, sodium benzoate, methylparaben, propylparaben, and aqua dest. The use of roasted robusta coffee bean extract as an antibacterial active ingredient. The use of xylitol as a sweetener. The use of sodium benzoate, methylparaben, and propylparaben, as preservatives. The use of aqua dest as a solvent. The use of glycerin in the formulation is to increase the solubility of the extract which is not completely soluble in water. Humectants such as glycerin are used 5-20\% in mouthwash to give a certain sensation in the mouth.

Mouthwash contains the active ingredient of roasted robusta coffee bean extract by $6 \%$ because it is based on previous research by Maheswari et al, (2015)Robusta coffee bean extract was able to inhibit the growth of S. mutans bacteria starting from a concentration of $1.56 \%$. Mouthwash preparations were made in three formulas with varying concentrations of glycerin, namely 5\%,10\%, and 15\%. Variations in glycerin concentration were carried out to determine the effect of humectants on the stability of the mouthwash and its inhibition against $\mathrm{S}$. mutans bacteria.

Table 1. Mouthwash Formulation (Gowtham et al., 2020)

\begin{tabular}{llccc}
\hline \multicolumn{1}{c}{ Ingredients } & Function & $\begin{array}{c}\text { Formula 1 } \\
\text { (\%) }\end{array}$ & $\begin{array}{c}\text { Formula 2 } \\
\text { (\%) }\end{array}$ & $\begin{array}{c}\text { Formula 3 } \\
\text { (\%) }\end{array}$ \\
\hline $\begin{array}{l}\text { Roasted robusta } \\
\text { coffee bean extract }\end{array}$ & $\begin{array}{l}\text { Antibacterial Active } \\
\text { Ingredients }\end{array}$ & 6 & 6 & 6 \\
\hline
\end{tabular}




\begin{tabular}{llccc}
\hline \multicolumn{1}{c}{ Ingredients } & \multicolumn{1}{c}{ Function } & $\begin{array}{c}\text { Formula } \\
\text { (\%) }\end{array}$ & $\begin{array}{c}\text { Formula 2 } \\
\text { (\%) }\end{array}$ & $\begin{array}{c}\text { Formula 3 } \\
\text { (\%) }\end{array}$ \\
\hline Xylitol & Sweetener & 2 & 2 & 2 \\
\hline Glycerin & Humectants & 5 & 10 & 15 \\
\hline Sodium Benzoate & $\begin{array}{l}\text { Preservative } \\
\text { (Bacteriostatic) }\end{array}$ & 0.1 & 0.1 & 0.1 \\
\hline Methyl Paraben & $\begin{array}{l}\text { Preservative } \\
\text { (Bactericidal) }\end{array}$ & 0.05 & 0.05 & 0.05 \\
\hline Propyl Paraben & $\begin{array}{l}\text { Preservative } \\
\text { (Bactericidal) }\end{array}$ & 0.01 & 0.01 & 0.01 \\
\hline Aquadest & Solvent & $100 \mathrm{~mL}$ & $100 \mathrm{~mL}$ & $100 \mathrm{~mL}$ \\
\hline
\end{tabular}

\section{Mouthwash Stability Test}

The mouthwash stability test was carried out with forced treatment conditions, namely storage at a temperature of $5^{\circ} \mathrm{C}$ and $35^{\circ} \mathrm{C}$ for 12 hours each for 10 cycles (Ririn et al., 2013). The following are the results of the stability test for mouthwash preparations:

\section{a. Organoleptic Examination Results}

Organoleptic examination of mouthwash preparations includes the examination of color, odor, and taste. These parameters are visual characteristics and physical characteristics that can be observed directly(Handayani et al., 2017). The results of organoleptic observations are based on table 2, namely, the three formulas have the same odor and color, have a distinctive coffee odor, and are brown. This is because all mouthwash formulas contain an active ingredient, namely ethanol extract of roasted robusta coffee beans with the same concentration. The mouthwash taste of the three formulas has the same taste, which is freshly sweet. The sweet taste is because the mouthwash contains a sweetener, namely xylitol and the fresh taste is due to the glycerin content which gives a certain sensation in the mouth (Suryani et al., 2019). There was no difference in sweet taste in the three formulas because the added concentration of xylitol sweetener was the same. The difference in the concentration of glycerin in each mouthwash formula did not result in a difference in the taste and sensation of the mouthwash in the mouth.

The results of organoleptic examination after accelerated storage did not change the smell, color, and taste of the mouthwash. This is because mouthwash contains preservatives, namely sodium benzoate, methylparaben, and propylparaben. Preservatives function to maintain the stability of the mouthwash in storage.

\section{b. pH test}

The $\mathrm{pH}$ value is very influential on the type of bacteria that can grow in a preparation. Most bacteria have an optimum pH value of around 6.5-7.5 (Lukas, 2012). Therefore, the mouthwash preparation that is made must be outside the $\mathrm{pH}$ value range. Based on table 2 the $\mathrm{pH}$ value obtained in each formula is 5 . The value obtained is by the $\mathrm{pH}$ of the mouthwash according to Hidayanto et al, (2017) which ranges from 5-7, besides that the $\mathrm{pH}$ obtained is outside the optimum $\mathrm{pH}$ range. for bacterial growth. The results showed that the $\mathrm{pH}$ of the mouthwash preparation did not change after the condition was forced. This indicates that the mouthwash formula has good $\mathrm{pH}$ stability. 


\section{c. Viscosity Examination Results}

The viscosity of the mouthwash formulation greatly affects the level of viscosity of the mouthwash when used to gargle in the mouth. The closer the viscosity level of the mouthwash formulation to the viscosity of water, the more comfortable and easy it is to use in the mouth. The viscosity of pure water is 1002 Pa.s or approx $\pm 0.010 \mathrm{P}$ (Luke, 2012).

The results of the viscosity analysis on each mouthwash formula showed that the viscosity value of the formula ranged from 0.0104-0.0158 P. The viscosity value of the mouthwash formula before and after the forced condition was formula 1 (0.0109; $0.0104) \mathrm{P}$, formula $2(0.0142 ; 0.0130) \mathrm{P}$, and formula $3(0.0158 ; 0.0146) \mathrm{P}$. The highest viscosity value is shown by formula 3 with the largest glycerin concentration of $15 \%$, while the lowest viscosity occurs in formula 1 with the smallest glycerin concentration of $5 \%$. The difference in viscosity values is caused by differences in the glycerin content in the formula. Based on the literature, glycerin has a viscosity value of $0.0114 \mathrm{P}$ at a concentration of $5 \%$ and $0.0131 \mathrm{P}$ at a concentration of $10 \%$ (Yosephine et al., 2013). The greater the glycerin content in the preparation, the greater the viscosity value of the preparation (Baitariza et al., 2020). Although the viscosity value obtained is greater than the viscosity value of water, it still meets the viscosity standard for commercial mouthwash preparations, which is $0.0725 \mathrm{P}$ (Noval et al., 2020).

The results of the viscosity measurement before and after the forced condition decreased the viscosity value in each preparation. The difference in storage temperature when conditions are forced results in a decrease in the viscosity of the preparation. The viscosity of the preparation will vary depending on the temperature, generally, the viscosity of the liquid decreases with increasing temperature (Ririn et al., 2013). The decrease in the value of the viscosity of the mouthwash after forced storage was also due to the solution form having a relatively shorter storage period when compared to the solid dosage form. This happens because the preparation in the form of a solution is easily decomposed by temperature and light, besides that it can react with the environment (Handayani et al., 2016). Although the value of the viscosity of the mouthwash formula decreased. However, statistically, there was no significant difference $(\alpha>0.05)$ between before and after the condition was imposed on all mouthwash formulas. It can be concluded that the three formulations of roasted robusta coffee bean ethanol extract mouthwash have storage stability.

Table 2. Mouthwash Stability Test Results

\begin{tabular}{|c|c|c|c|c|c|c|c|}
\hline \multirow{2}{*}{\multicolumn{2}{|c|}{ Checking type }} & \multicolumn{6}{|c|}{ Mouthwash Preparations } \\
\hline & & \multicolumn{2}{|c|}{ Formula 1} & \multicolumn{2}{|c|}{ Formula 2} & \multicolumn{2}{|c|}{ Formula 3} \\
\hline \multirow{4}{*}{ Organoleptic } & & Before & After & Before & After & Before & After \\
\hline & Smell & $\begin{array}{c}\text { Typical } \\
\text { coffee }\end{array}$ & $\begin{array}{c}\text { Typical } \\
\text { coffee }\end{array}$ & $\begin{array}{c}\text { Typical } \\
\text { coffee }\end{array}$ & $\begin{array}{c}\text { Typical } \\
\text { coffee }\end{array}$ & $\begin{array}{c}\text { Typical } \\
\text { coffee }\end{array}$ & $\begin{array}{c}\text { Typical } \\
\text { coffee }\end{array}$ \\
\hline & Flavor & $\begin{array}{l}\text { Fresh } \\
\text { sweet }\end{array}$ & $\begin{array}{l}\text { Fresh } \\
\text { sweet }\end{array}$ & $\begin{array}{l}\text { Fresh } \\
\text { sweet }\end{array}$ & Fresh sweet & $\begin{array}{l}\text { Fresh } \\
\text { sweet }\end{array}$ & $\begin{array}{l}\text { Fresh } \\
\text { sweet }\end{array}$ \\
\hline & Color & Chocolate & Chocolate & Chocolate & Chocolate & Chocolate & Chocolate \\
\hline \multicolumn{2}{|l|}{ pH } & 5 & 5 & 5 & 5 & 5 & 5 \\
\hline \multicolumn{2}{|c|}{ Viscosity (P) } & 0.0109 & 0.0104 & 0.0142 & 0.0130 & 0.0158 & 0.0146 \\
\hline
\end{tabular}




\section{Effectiveness Test of Roasted Robusta Coffee Bean Extract Mouthwash (Coffea canephora) Against S. mutans Bacteria}

The effectiveness test of the ethanol extract of roasted robusta coffee bean mouthwash formula against S. mutans bacteria was carried out using the agar diffusion method. The measurement results showed that all mouthwash formulas had an antibacterial activity with a weak category (diameter $<5 \mathrm{~mm}$ ).(Handayani et al., 2017). The following are the results of the inhibition zone measurements formed from each formula and control in millimeters ( $\mathrm{mm}$ ):

Table 3. Results of Inhibitory Effectiveness Test Against S. mutans . bacteria

\begin{tabular}{cccccc}
\hline Repitations & $\begin{array}{c}\text { Formula } \mathbf{1} \\
\text { (mm) }\end{array}$ & $\begin{array}{c}\text { Formula } 2 \\
\text { (mm) }\end{array}$ & $\begin{array}{c}\text { Formula } 3 \\
(\mathbf{m m})\end{array}$ & $\begin{array}{c}\mathbf{( + )} \\
\mathbf{( m m )}\end{array}$ & $\begin{array}{c}\mathbf{( - )} \\
\mathbf{( m m})\end{array}$ \\
\hline I & 1.8 & 1.7 & 2.2 & 6.8 & 0 \\
\hline II & 1.6 & 2.9 & 3.2 & 6.9 & 0 \\
\hline III & 1.4 & 1.8 & 1.8 & 6.8 & 0 \\
\hline Average \pm SD & $1.6 \pm 0.2$ & $2.1 \pm 0.7$ & $2.4 \pm 0.7$ & $6.8 \pm 0.05$ & 0 \\
\hline
\end{tabular}

The data in table 3. then tested for normality with Shapiro-Wilk. The significance value obtained is less than 0.05 , so it can be concluded that the data are not normally distributed. After the data is said to be not normally distributed, a non-parametric alternative test is conducted in the form of the Kruskal Wallis test. The results of the Kruskal Wallis test can be seen in the following table:

Table 4. Kruskal Wallis. Test Results

\begin{tabular}{ccc}
\hline df & asymp. Sig. & Description \\
\hline 4 & 0.014 & Significantly different \\
\hline
\end{tabular}

Table 4. shows the values obtained $<0.05$, meaning that the inhibition of $\mathrm{S}$. mutans in the control group and the treatment group had a significant difference. To find out which treatment groups were significantly different, further tests were carried out with Mann Whitney.

The results of the Mann-Whitney test in table 5. show that there is a significant difference between the negative control and the mouthwash formula, both formulas 1,2 , and 3. It can be seen that there are also significant differences between the positive control and the mouthwash formula, both formula 1, 2, and 3, but also significantly different from the negative control. No significant difference was found in each mouthwash formula.

Table 5. Mann Whitney. Test Results

\begin{tabular}{|c|c|c|c|c|c|}
\hline \multirow{2}{*}{$\begin{array}{c}\text { Treatment } \\
\text { Group }\end{array}$} & \multicolumn{5}{|c|}{ Significance Value $(\alpha)$} \\
\hline & Formula 1 & Formula 2 & Formula 3 & Control (+) & Control (-) \\
\hline Formula 1 & & 0.184 & 0.077 & $0.046^{*}$ & $0.037^{*}$ \\
\hline Formula 2 & & & 0.376 & $0.046^{*}$ & $0.037^{*}$ \\
\hline Formula 3 & & & & $0.046^{*}$ & $0.037^{*}$ \\
\hline Control (+) & & & & & $0.034^{*}$ \\
\hline Control (-) & & & & & \\
\hline
\end{tabular}


The antibacterial test was carried out using the agar diffusion method. The clear zone formed around the disc proved that the mouthwash formula of roasted robusta coffee bean extract had antibacterial activity against S. mutans. Based on table 3. above, it can be seen that the three mouthwash formulas can inhibit the growth of $\mathrm{S}$. mutans bacteria with different diameters. The greater the glycerin content in the mouthwash formula, the greater the inhibitory power. This is because glycerin is a humectant function to increase the contact time of the mouthwash formula with bacteria. In addition, glycerin also helps to maintain the evaporation of excess water in the preparation (Anastasia et al., 2017). However, statistical analysis showed that there was no significant difference $(\alpha>0.05)$ between formula 1 , formula 2 , and formula 3 . So it can be concluded that the variation of glycerin has no significant effect on the antibacterial effectiveness of mouthwash. There is an assumption that the greater the glycerin content in the formula, the better the antibacterial effectiveness. This assumption does not apply in this study. This can happen because according to Rowe et al (2009), in HPE page 301, the working activity of glycerin can be reduced if there is an interaction with phenol/polyphenol compounds in inappropriate concentrations. This assumption does not apply in this study. This can happen because according to Rowe et al (2009), in HPE page 301, the working activity of glycerin can be reduced if there is an interaction with phenol/polyphenol compounds in inappropriate concentrations. This assumption does not apply in this study. This can happen because according to Rowe et al (2009), in HPE page 301, the working activity of glycerin can be reduced if there is an interaction with phenol/polyphenol compounds in inappropriate concentrations.

according to Handayani et al., (2017), The antibacterial inhibition was divided into very strong (clear zone $>20 \mathrm{~mm})$, strong $(10-20 \mathrm{~mm}$ clear zone), moderate $(5-10 \mathrm{~mm}$ clear zone), and weak (clear zone $<5 \mathrm{~mm}$ ). Based on the research that has been done, formula 1 produces an inhibition zone of $1.6 \mathrm{~mm}$, formula 2 produces an inhibition zone of $2.1 \mathrm{~mm}$, formula 3 produces an inhibition zone of $2.4 \mathrm{~mm}$ so that the inhibitory ability produced by the three ethanol extract mouthwash formulas Roasted robusta coffee beans can be categorized as weak. The negative control used did not produce inhibition against S. mutans. The positive control showed the presence of antibacterial activity against $\mathrm{S}$. mutans with an inhibition zone diameter of $6.8 \mathrm{~mm}$ in the medium category.

There are differences in the results of the effectiveness of the inhibitory power of chlorhexidine positive control against $\mathrm{S}$. mutans bacteria with previous studies conducted by Sinaredi et al. (2014), in his research chlorhexidine had an inhibitory power of $16 \mathrm{~mm}$ with a strong category. Another study conducted by Suryani et al. (2014) also resulted in different inhibitory effectiveness, which was $29.1 \mathrm{~mm}$ in the very strong category. The difference in effectiveness could be caused by, among others, the difference in the number of colonies of S. mutans bacteria because in this study there was no comparison of bacterial suspension with Mc Farland standards, and mutations or bacterial contamination occurred during storage, causing resistance to antibacterial compounds.

Previous research conducted by Maheswari et al, (2015) investigated the inhibitory power of robusta coffee bean extract on the growth of S. mutans bacteria. It is stated that robusta coffee bean extract can inhibit the growth of S. mutans bacteria starting from a concentration of $1.56 \%$. This is in line with the research conducted, namely the formulation of mouthwash of roasted robusta coffee bean extract with a concentration of $6 \%$ can inhibit the growth of S. mutans bacteria with a weak category. 
Chemical compounds contained in the ethanol extract of roasted robusta coffee beans that act as antibacterial are caffeine, chlorogenic acid (CGA), caffeic acid, and trigonelline (Siebert et al., 2018). Caffeine is an alkaloid compound. The content of alkaloids in the ethanol extract of roasted robusta coffee beans has the antibacterial ability because it has a quaternary aromatic group capable of intercalating with DNA, alkaloids also interfere with the integrity of the peptidoglycan constituent components in bacterial cells.(Rahman et al., 2017).

Chlorogenic acid and trigonelline are compounds of the flavonoid group. Flavonoid compounds are antibacterial through 3 mechanisms, namely: inhibiting nucleic acid synthesis, inhibiting cell membrane function, and inhibiting energy metabolism.(Rahman et al., 2017). Brooks et al (2010) stated that the structure of the bacterial cell wall also plays a role in determining the binding, penetration, and activity of an antibacterial compound.

The content of other compounds in roasted robusta coffee bean extract that has antibacterial activity is saponins and tannins. Saponins work effectively on gram-positive bacteria such as S. mutans. The antibacterial action mechanism of saponins is by increasing the permeability of the cell membrane so that the membrane becomes unstable and results in cell hemolysis (Dewi et al., 2015). The content of tannin compounds in the ethanol extract of roasted robusta coffee beans has antibacterial action related to its ability to deactivate bacterial adhesion, inhibit enzyme activity, and inhibit protein transport in the cell envelope. The mechanism of action of tannins as antibacterial agents is through the destruction of bacterial cell membranes due to tannin toxicity and the formation of metal ion complex bonds from tannins which play a role in tannin toxicity.(Rahman et al., 2017). According to Xie et al, (2008) tannins have the effect of inhibiting the growth of $S$. mutans bacteria.

The results of statistical analysis showed that the data obtained were not normally distributed. The analysis was continued with a non-parametric test, namely KruskalWallis, and obtained a significance value of $<0.05$, meaning that the inhibitory power of $S$. mutans in each treatment group had a significant difference. The results of the MannWhitney test in table 5. show that there is a significant difference between the mouthwash formula and the negative control. This indicates that the mouthwash formula has antibacterial activity against S. mutans. The effectiveness of mouthwash was smaller when compared to the positive control. It can be seen that there is a significant difference between the mouthwash formula and the positive control in the test.

The results of the measurement of the diameter of the inhibition zone showed that the higher the glycerin content in the mouthwash formula, the greater the antibacterial effectiveness against S. mutans. But statistically, it can be concluded that the variation of glycerin has no significant effect on the antibacterial effectiveness of mouthwash. Variations in glycerin also did not significantly affect the stability of mouthwash preparations. So that the best mouthwash formula used is mouthwash formula 1 with $5 \%$ glycerin content which has a viscosity value closest to the viscosity of water. The closer the viscosity level of the mouthwash formulation to the viscosity of water, the more comfortable and easy it is to use in the mouth (Lukas, 2012). 


\section{CONCLUSIONS}

\section{Conclusion}

Based on the results of the research that has been done, the following conclusions can be drawn:

a. The three formulations of roasted robusta coffee bean ethanol extract mouthwash with variations of glycerin $5 \%, 10 \%$, and $15 \%$ had $\mathrm{pH}$, organoleptic, and viscosity stability. The results of statistical analysis showed that the viscosity of the three mouthwash formulas did not have a significant difference before and after the forced condition.

b. The three formulas of mouthwash of roasted robusta coffee bean extract had antibacterial activity against $\mathrm{S}$. mutans with a weak category (diameter $<5 \mathrm{~mm}$ ). The results of statistical analysis showed that variations in glycerin had no significant effect on the antibacterial effectiveness of mouthwash.

\section{Suggestion}

Suggestions from this research include:

a. Further research needs to be done using positive control in the form of herbal mouthwash to compare the antibacterial effectiveness between mouthwash and herbal active ingredients.

b. It is necessary to research the activity of mouthwash against other bacteria that cause dental caries.

\section{REFERENCES}

AAP Almeida, CC Naghetini, VR Santos, AG Antonio, A. Farah, MBA Gloria, (2012), Influence of natural coffee compounds, coffee extract and increased levels of caffeine on the inhibition of Streptococcus mutans, Food Research International, 49: 459 461.

Anastasia, A., Yuliet, Tandah, MR, (2017), Formulation of Mouthwash Preparations for Preventing Dental Plaque Cocoa Seed Extract (Theobroma cacao L) and Effectiveness Test on Streptococcus mutans Bacteria, GALENIKA Journal of Pharmacy, 3 (1): 84 92.

Baitariza, A., Ghazali, A., Rosmiati, (2020), Formulation of Mouthwash Solution for Preventing Dental Plaque Pineapple Peel Extract (Ananas comosus L. Merr), Sabdariffarma Journal, 6 (1):33-42.

Brooks GF, Carol KC, Butel JS, Morse SA, Mietzner TA. Jawetz, Melnick \& Adelberg Medical Microbiology 25th Edition. The McGraw-Hill Companies. US; 2010. 56 - 62, 339 - 370.

Chairgulprasert, V. \& K. Kittiya, (2017), Preliminary phytochemical screening and antioxidant of robusta coffee blossom, Thammasat International Journal of Science and Technology, Thailand, 22 (1): 18.

Chamidah, S., (2012), Antibacterial Power of Robusta Coffee Bean Extract (Coffea canephora) Against the Growth of Porphyromonas gingivalis [Thesis]. Faculty of Dentistry, University of Jember, Jember, Indonesia. 
Dewi, et al., (2015), Antibacterial Effects and Biofilm Inhibition of Lemongrass Extract (Cymbopogon Nardus L.) Against Streptococcus mutans, Indonesian Dentistry Magazine, 1 (2): 136 - 141.

Efendi, Nur Rohman, (2017), Effect of Giving Ethanol Extract of Karika Fruit (Carica pubescent L.) on Lipid Peroxidation (LPO) Activity of Paracetamol Induced Rat Liver, Thesis, Faculty of Mathematics and Natural Sciences, Sebelas Maret University, Surakarta.

Farah, Adriana., Carmen MD, (2012), Phenolic Compounds in Coffee. Braz. J. Plant Physiol, 18(1):23-36.

Gowtham, A. et al., (2020), Comparative Evaluation Of Antibacterial Efficacy Of Green Coffee Bean Extract Mouthwash and Chlorhexidine Mouthwash Against Streptococcus Mutans and Lactobacilli Spp. - An In Vitro Study, Indian Journal Of Health Sciences and Biomedical Research KLEU, 13 (2).

Handayani, F., Sundu, R \& Ria, MS, (2017), Formulation and Test of Streptococcus mutans Antibacterial Activity from Mouthwash Preparations Guava Leaf Extract (Psidium guajava L.), Journal of Science and Health, 1 (8): 422- 433.

Hidayanto, A., Manikam. AS, Pertiwi, WS \& Harismah, K., (2017), Basil (Ocimum basilicum L.) Leaf Extract Mouthwash Formulation with Stevia (Stevia rebaundiana Bortoni) Natural Sweetener, The 6th University Research Colloqium, University of Muhammadiyah Magelang, Indonesia.

Kiattisin, K., Nantarat, T., Leelapornpisid, P., (2016), Evaluation of Antioxidant and AntiTyrosinase Activities As Well As Stability of Green and Roasted Coffee Bean Extracts From Coffea Arabica and Coffea Canephora Grown In Thailand, Journal of Pharmacognosy and Phytotherapy, 8(10): 182-192.

Lukas A, (2012), Gambir Mouthwash Formulation With Added Peppermint and Clove Oil, Journal of Industrial Research Dynamics, 23: (2).

Maheswari, RA, Krismariono, A., \& Bargowo, L, (2015), Inhibitory Power of Robusta Coffee Bean Extract (Coffea Canephora) Against the Growth of Plaque Bacteria. 6.

Maheasy FL and Atun S, (2017), Antibacterial Activity Test of TemuKEY (Boesenbergia Pandurata) Ethanol Extract Against Streptococcus Mutans Bacteria, Scientific Journal of Research, 22: (1).

Oelviani and Hermawan, (2017), The Need for Coffee Technology in Central Java (Case Study of Coffee Commodities in Temanggung Regency), National Development Planning Agency BAPPEDA Central Java Province 2017.

Rahman, et al, (2017), Phytochemical Screening and Antibacterial Activity of Soursop Leaf (Annona muricata L.) Ethanol Extract on Streptococcus mutans ATCC 35668, Indonesian Dentistry Magazine I, 3: (1).

Ririn, et al., (2013), Formulation of Mouthwash Preparations From Betel Juice (Piper beetle L.) Siriboah Varieties, As-Syifaa, 5 (02): 153-161. 
Rowe, Raymond C, et al. (2009). Handbook of Pharmaceutical Excipients, 6th Ed. Pharmaceutical Press, USA. Page: 301.

Siebert M, Berger RG, Nieter A. (2018), Enzymatic mitigation of 5-0-chlorogenic acid for an improved digestibility of coffee, Food Chem, 03.061:124-128.

Sinaredi, BR., Pradopo, S., Wibowo, TB, (2014), Antibacterial Power of Chlorhexidine Mouthwash, Povidone Iodine, Zinc Supplementation Fluoride Against, Streptococcus Mutans and Porphyromonas

Suryani, N., Adini, S., Stiani, SN, Indriatmoko, DD, (2019), Herbal Mouthwash Containing Ethyl Acetate Extract of Bintaro Bark (Cerberra Odollam Gaertn) As Antibacterial Streptococcus Mutans Causes Dental Plaque, Farmaka, 17 (2).

Tanauma, HA., Citraningtyas, G., Lolo, WA., (2016), Antibacterial Activity of Robusta Coffee Bean Extract (Coffea canephora) Against Escherichia coliI Bacteria, PHARMACON Pharmaceutical Scientific Journal I, 5: (4).

Utami, NF, Nhestricia, N., (2018), The Test of Antioxidant Activities With Comparison of Extraction Methods From Robusta Coffee Seeds (Coffea canephora), JOURNAL OF SCIENCE INNOVARE, 01 (02): 60-63.

Xie Q, Li J, Zhou X, (2008), Anticaries effect of compounds extracted from Galla chinensis in a multispecies biofilm model, Oral Microbiol Immunol, 23: $459-465$.

Yaqin, MA, M. Nurmilawati, (2015), Effect of Robusta Coffee Extract (Coffea robusta) as a Growth Inhibitor, XII National Seminar on Biology Education FKIP UNS.

Yosephine, AD, Wulanjati, MP, Saifullah, TN, \& Astuti, P., (2013), Mouthwash Formulation of Basil Leaves Essential Oil (Ocimum basilicum L.) And Antibacterial and Antibiofilm Tests against Streptococcus mutans Bacteria In Vitro, Trad. Med. J., 18(2), 95-102.

Yusmarini, (2011), Polyphenol compounds in coffee: influence of processing, metabolism and its relationship with health, SAGU Journal, 10 (2): 22-30.

Yusianto., Dwi N., (2014), Physical Quality and Taste of Arabica Coffee Stored Before Pulping, Pelita Perkebunan, 30 (2): 137-158. 